\title{
Corruption, Foreign Direct Investment and its Impact on Exchange Rate of the Nigerian Economy
}

\section{Eravwoke Kester Erhieyovwe}

\author{
College of Physical Education, \\ Mosogar Delta state Nigeria. \\ e- mail: kester442002@yahoo.com
}

Imide Isreal Onokero

College of Education

Agbor Delta state, Nigeria.

\section{Doi:10.5901/mjss.2013.v4n3p345}

\begin{abstract}
This paper seeks to analyze corruption, foreign direct investment and its impact on exchange of the Nigerian economy. The ultimate objective of this study centers on an empirical investigation of the impact of corruption, foreign direct investment and its impact on exchange rate of the Nigerian economy. In order to achieve these objectives the study used the ordinary least squares regression analyses, augmented dickey fuller unit root test and the co-integration test. The unit root test revealed that all the variables were stationary at first difference and the short run result revealed that corruption is very high in Nigeria and that have help to depreciate the currency of the country with regards its exchange to other currencies. The study recommends that war against corruption or state of emergency on corruption should be vigorously pursued, this will help to remold the image of the Nigerian economy and encourage more foreign investors that will help to equate our exchange rate to other currencies
\end{abstract}

\section{Introduction}

Wide spread corruption seems to be one of the main factors that prevent poor and developing countries to catch up with the rich and developed ones. Although corruption was not given an explicit recognition in the traditional economic theories, it has in recent times become a globally recognized policy variable especially in less developed countries. There are two major views in empirical research as regards the impact of corruption. The first school of thought perceived corruption as having a relatively low transaction costs compared to the benefits derived from increase in employment and income. Bribery is perceived to help grease the wheel from immediate transaction and contractual businesses. This view was based mainly on "coarsion theory" which states that market transactions are costless; a rearrangement of right will always takes place if it leads to an increase in production value (Prakasam. 2008). Also, corrupt practices such as speed money is perceived to be capable of enabling individuals to avoid bureaucratic delays and that government employees who are allowed to levy bribes would work harder thus having a positive return on investment (Leff, 1964). However, on the other hand the unanimous view supported by World Bank, United Nations Development Programme (UNDP), Organization of Economic Cooperation and Development (OECD) and a host of many writers (Mauro, 1995; Wei, 1995; Kauffmann, 1997; Mo, 2001; Aliyu and Elijah, 2008) was that corruption exerts long term adverse effects on macroeconomic growth and development. The transmission of these adverse effects include declined domestic and foreign investment, increased cost of doing business and production, increased inequality and poverty, misallocation of national resources among others (Aliyu and Elijah, 2008).

After more than four decades of developmental efforts and management, Nigeria is still being classified as an underdeveloped poor country of the Third World. Despite being one of the richest countries in the world, in terms of human and natural resources, with one of the seventh largest reserves of crude oil, the country is still living below the poverty line with a gross national product per capita of N1,220. For instance, over the past twenty years, Nigeria has generated approximately \$360billion from oil revenue, yet, she remains poor. The indexes of development for Nigeria prove this. For instance, Nigeria's maternal mortality rate remains one of the highest in the Africa continent standing at 100 for every 100,000 births. Life expectancy remains 52 years as at 2008. Less than 67 percent of Nigerians have 
access to good health services. Only 19 medical doctors are available per 100,000 persons as against 16 nurses. Only 42 percent have access to safe water.

The 2005 UNDP human development index ranks Nigeria 158th out of 159 countries of Third World Nations in terms of underdevelopment. The under-developmental situations of Nigeria, in spite of its enormous natural and human resources are worrisome. Among other variables, some researchers have identified corruption as one of the major factors responsible for underdevelopment of Nigeria's economy. For example Akindele (2005) undertook an econometric investigation of the relationship between a numbers of key variables in Nigeria. Estimating a modified production function, which includes labour, capital, Political instability, corruption and income inequality, he concluded that the co-efficient of the corruption index is negative implying that it is consistent with the hypothesis that corruption retards development efforts. It has been noted that where corruption exists, even a highly endowed nation in terms of natural and human resources may fail to develop in a beneficial way to a great majority of the citizens. It is a fact that this problem has been in Nigeria for some time now, the magnitude and intensity of which increase from year to year. It is an open secret that an average Nigerian is corrupt. Although, it is difficult to compile comprehensive data on corruption manifested in bribery, frauds, embezzlement etc, notwithstanding official politics in Nigeria since 1975 and up till now validate the presence of corruption, Osunyikanmi (2007).

The main objective of this paper is to analyze the impact of Corruption on major Macro economic variables in Nigeria. Specifically the paper hopes to find:

i. the impact of corruption on Investment

ii. the impact of corruption on Money supply

iii. the impact of corruption on Gross domestic product

The Hypotheses to be tested are:

i. there is no significant relationship between corruption and Investment

ii. there is no significant relationship between corruption and Money supply.

iii. there is no significant relationship between corruption and Gross domestic product.

\section{Literature Review on Corruption}

The corruption issues have scanty literature on concepts, determinants, severity and implications on economic development. The reason for the lack of interest in this area of research is because data are not readily available, particularly when we need to pin- point the size of corruption and the people that engage in it. Notwithstanding, certain authors such as Ngouo, Tanzi, Rose Ackerman and Akindele have studied corruption, given some definitions, and examined the determinants and implications of corruption. According to Ngouo (2000) and the World Bank, corruption is the exploiting of public positions for private benefits. She also states that the lack of any civil spirit among all categories of civil servants leads to corruption and misappropriation of public funds. To Tanzi et al (2006), corruption is not only found in the public sector, it is equally prominent in the private sectors; Akindele (2005) sees corruption as behavior, which deviates from the formal rules of governing the actions of someone in a position of authority. According to Osunyinkanmi (2009), the term corruption is a synonym with the terms fraud, bribery, settlement etc. In his explanation, the settlement in corruption perception parlance became a euphemism for bribery in Nigeria during the Babangida administration in 1989. In support of Osunyinkanmi's view, Rose Ackerman (1992) opines that corruption can assume several forms such as bribery, embezzlement, fraud etc, where bribery assumes the most predominant forms of corruption. Rose - Ackerman (1998) further submits that bribery could manifest in incentive payments, obtaining lower cost and buying influence or votes. While Dwivedi (1967), sees corruption as including "nepotism, favouritism, bribery, graft and other unfair means adopted by government employees and the public alike to extract some socially and legally prohibited favours". To Scott (1972), corruption "involves a deviation from certain acceptable standards of behaviour".

Several schools of thought have discerned the factors that determine corrupt practices in the society. For instance in 1995, USA secretary of state viewed corruption from the cultural perspective. According to this school of thought, it is in the Nigerian culture to be corrupt. While this argument might appear reasonable, it is however not a universal phenomenon. For instance, former socialist states of the defunct USSR such as Kazakhstan, Uzbekistan, Russia, Ukraine and Azerbaijan, held contrary views. According to them, corruption is not a cultural phenomenon but rather a practice that supersedes culture and custom. It is universal. This view was corroborated by Akindele (1990) who stated that corruption exists everywhere, a statement that repudiates a racial and regional bans of corruption. The most plausible arguments in this area would seem to be that corruption is intractably determined by the stage of development and the type of government that exists in a society or nation. In most of the high corrupt countries like Nigeria, 
government bureaucracy creates the atmosphere conducive for corruptions. Authors like Rose Ackermen (1998), Tanzi et al (2006) and Obadan (2001), have noted that governments of certain countries for political or other reasons create incentives for bribery and corruption and are sometimes directly involve in the corrupt practices. In some extreme cases, the government itself practices corruption in order to have their way through the legislative arms. This practice is quite common in Nigeria. Other determinants of corruption include the level of salary and the level of wealth. The lower the salaries and wages of public officers, the greater the tendency for them to be corrupt.

\section{Measures of Fighting Corruption in Nigeria}

The nature of corruption in Nigeria is as Kolade (1999) and Ogboru (2009) put it, such that corruptible transactions take place i.e. where award of government contracts which are grossly inflated by government officials to friends, their family members or even to themselves directly for self enrichment at the expense of the populace and the nation. Transparency International, 2000 global report rated Nigeria as the 2nd most corrupt country on earth, among 89 countries in the world, using its corruption perception index (CPI). The spate of corruption in Nigeria necessitated the setting up of the following:

The Justice Anthony Okuribido panel to probe the contracts awarded by the Federal Ministry of works between 1979 and 1983. Nothing came out of the report, although it was discovered that numerous contractors owed the federal government over N24million for contracts paid but not executed. The late Sani Abacha was hard on corruption. He declared War against Indiscipline and Corruption (WAIC), but it was all lip service to the social malaise. (c) The Christopher Kolade.s panel which was constituted by Obasanjo to review contracts, licenses and appointments. The tribunal was to try fraudulent officers of the Abdulsalam Abubakar.s Military administration. The panel's final report was not implemented. The Justice Kayode Eso panel to clean up the steep corruption in the nations Judiciary. The panel indicted 47 Judges whom the report stated were not worthy to retain their seats on the bench. Only a few of them were dealt with. The government established the Independent Corrupt Practices Commission and the Economic and Financial Crime commission in 2000 and 2003 respectively. Though many state governors have been indicted by these commissions for misappropriation of public funds and personal enrichments they are yet to be brought book. This major lapse has eroded the confidence of the masses in the commissions.

\section{Methodology}

In estimating the model for the study, we used three steps methodology. These steps include:

1. Univariate statistical analysis of time series (Test for unit root) to ascertain the stationarity and non stationarity status of the data series.

2. Co- integration analysis and the estimation of long run equilibrium models on corruption, foreign direct investment and its impact on exchange rate using Johansen co-integration test.

3. Short run analysis using the ordinary least squares regression method to see the impact of the independent variables on the dependent variable.

\section{The Model}

Based on the literature review an empirical corruption and exchange rate model can be derived from this study.

Specifically, Exchange rate (EXR) can be modeled as a function of corruption index (Cl), Inflation (INF), and foreign direct investment (FDI).

$E X R=\partial l+\partial 2 \mathrm{Cl}+\partial 3 \mathrm{INF}+\partial 4 \mathrm{FDI}+\mathrm{a}$

Where $a$ is the error term

\section{Nature and sources of Data}

Annual time series data on the selected variables for Nigeria are used for the study. The sample point for the period is 1980 - 2011. The variables used are corruption index (CI), Inflation (INF), foreign direct investment (FDI) and Exchange rate (EXR). The data were obtained from various issues of Central Bank of Nigeria statistical bulletin, Bureau of statistics etc. 


\section{Empirical Results}

The current specification and estimation of our model require that we test the time series properties of data in order to determine whether or not the variables contain integrated components. Hence we undertake the standard Augmented Dickey - Fuller (ADF) test (Dickey and Fuller, 1981). This is used in preference to the alternative non- parametric test proposed by Phillips and Peron (1988) as the PP has been found to have poor size properties (i.e the tendency to over reject the null hypothesis when it is true) (Robinson, M.O and Okowa, E 2011).

\section{Time Series Properties of Data}

\subsection{Unit Root Tests}

Table 1, below shows the unit root test on the order of integration (stationarity test) of the variables (dependent and independent) based on the Augmented Dickey Fuller (ADF) classes of unit root tests. The ADF test the null hypothesis for variables of interest that are non stationary and ascertain the number of times a variable needs to be differenced to arrive at stationarity. As seen in the unit root test result, corruption (as proxied by corruption index), Inflation (INF) and foreign direct investment (FDI) are stationary at first difference judging from the Mackinnon critical values for rejection of unit root. This means that all the variables are stationary after taking their first difference.

Table 1: Unit Root Test

\begin{tabular}{lcccc} 
Variables & EXR & CI & FDI & INF \\
& -3.401096 & -5.035431 & -8.784722 & -5.618781 \\
Order of & $1(1)$ & $1(1)$ & $1(1)$ & $1(1)$ \\
Integration & \multicolumn{4}{l}{} \\
Critical values: $1 \%=3.6752,5 \%=-2.9665,10 \%=$ & -2.6220.
\end{tabular}

Variables can be stationary at $1(0)$, or after first difference depending on the value of Augmented Dickey Fuller test statistics and the critical value at 1 per cent, 5 per cent or 10 per cent level of significance. A variable that is stationary after first difference is said to be integrated of order 1 and that which is stationary at levels is order 0 .

It is when all the variables have attained the stationarity state that we can call for long run relationship. We can determine the existence of long run relationship between the variables. The co-integration test indicates there is one cointegrating equation at 5 per cent level. This confirms the existence of long run relationship among the variables.

Table 2: Results of Johansen co-integration Test

Test assumption: linear deterministic trend in the Data

Series: EXR CI INF FDI

Lags interval: 1 to 1

\begin{tabular}{|c|c|c|c|c|}
\hline Eigenvalue & Likelihood & $5 \%$ critical value & $1 \%$ critical value & Hypothesized No. of CE(S) \\
\hline 0.624216 & 52.25274 & 47.21 & 54.46 & None $^{*}$ \\
\hline 0.417019 & 22.89055 & 29.68 & 35.65 & At most 1 \\
\hline 0.188596 & 6.702535 & 15.41 & 20.04 & At most 2 \\
\hline 0.014325 & 0.432869 & 3.76 & 6.65 & At most 3 \\
\hline
\end{tabular}

${ }^{*}(* *)$ denotes rejection of the hypothesis at $5 \%(1 \%)$ significance level

L.R. test indicates I co-integrating equation(s) at $5 \%$ significance level

\subsection{Short run Result}

The short run result in the model shows that the independent variables explained 43 per cent variation or changes in corruption and foreign direct investment in Nigeria. The F statistics with a value of 7.260917 shows the equation has a good fit which mean that the explanatory variables are good explainer of the changes in exchanges rate in Nigeria. The 
Durbin Watson statistics of 0.689320 illustrate the presence of autocorrelation. This is not a problem as the major aim of this paper is not met forecasting. According to Teigen D.I (1964) concluded that there is no significant difference in performance between model with autocorrelation and those without auto correlation.

Table 3: Summary of Short Run Result

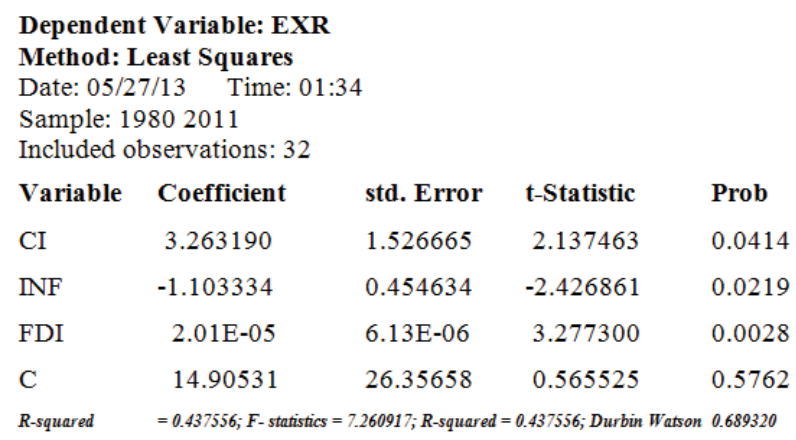

The corruption index was found to have a positive sign, this mean a 1 per cent increase in corruption level in the host community will lead to a 3.2631900 increase in exchange rate of the Nigerian economy. Foreign direct investment was found to have a positive sign, this equally mean that a 1 per cent increase in foreign direct investment will lead to a 2.01 increase in exchange rate. The implication of this is that a country can have increase in foreign direct investment and still have an increase in exchange rate because the foreign direct investors might not be involved in production locally and send to other countries that will enable the host community currency to appreciate with regards other currency. On the other hand, if foreign direct investment increases and productions are done locally and exported it will help our Naira appreciate with regards other currency.

The t- statistics suggest that corruption index with a value of 2.137463 is statistically significant in explaining the level of changes in exchange rate. The implication of this result is that when corruption in a country is very high it will help to depreciate the currency of the host community (Nigeria) with regards its exchange to other currency. For example like what we have in Nigeria today, since corruption has eaten deep into the Nigerian economy a dollar is being exchanged for about one hundred and sixty naira (\#160) you can imagine the huge difference. For inflation with a value -2.426861 and foreign direct investment with a value of 3.277300 are equally statistically significant in explaining the level of changes in exchange rate of the Nigerian economy.

\section{Policy implication and Recommendations}

Some policy implications can be gleaned from our findings. In view of the findings the following suggestions have been made.

Firstly, war against corruption or state of emergency on corruption should be vigorously pursued, this will help to remold the image of the Nigerian economy and encourage more foreign investors that will help to equate our exchange rate (i.e Naira) to other currencies, by so doing it will help to foster growth of the Nigerian economy.

Secondly, the Nigerian government should try as much as possible to encourage and patronize locally made goods and services that will help make our currency appreciate to other currencies.

It is recommended that the Nigerian government should strengthen the anti graft agencies like the Economic and financial crime commission (EFCC) and the independent corrupt practice and related offences commission (ICPC) and equally to leave politics out of their activities because in Nigeria once you are a big man or a big time politician activities of the EFCC and ICPC will never catch up with you even when the evidence of corruption is there.

\section{References}

Prakasam S.(2008): Corruption and Economic Growth. Retrieved from www.google.com. March 2010.

Leff, N.H. (1964). "Economic Development Through Bureaucratic Corruption." American Behavioral Scientist, 8(3):8-14.

Mauro, P. (1995), "Corruption and Growth." Quarterly Journal of Economics, 109, 681-712. 
Wei, S. J. (1995), "How Taxing is Corruption on International Investors?," NBER Working Paper 6030.

Mo, P. H. (2001). "Corruption and Economic Growth" Journal of Comparative Economics, 29, 66-79.

Kaufmann, D, Kraay A and Zoido-Lobatón P. (1999). "Governance Matters," World Bank Policy Research Working Paper No. 2196 (Washington: World Bank).

Aliyu S. U. R. and Elijah A. O (2008) Corruption and Economic Growth in Nigeria: 1986 - 2007. Munich Personal RePEc Archive (MPRA) No 12504. January.

Akindele ST (2005). A Critical Analysis of Corruption and its Problems in Nigeria. Anthropologist, 7(1): 7-18

Akindele ST (1990). Corruption and Economic Retardation: A Retrospective Analysis of Nigeria's Experience since Independence. In: Readings in the Political Economy of Nigeria Since Independence,

Osunyikanmi PO (2007). Development Implication of Nigeria's Economic Crisis' J. Dev. Persp. 2(1): 34-59.

Tanzi V, Davodi B, Sesan A (2006). Fighting Corruption in Nigeria Challenges for the future PPC Ibadan.

Ngouo L (2000). 'Responsibility and Transparence in Organization in Cameroom' in Makandala, R.S [ed], African Public Administration Zimbabwe APPS Books.

Rose A (1990). Corruption and Government Causes, Consequence and Reform, Cambridge UK Cambridge University press.

Osunyikanmi PO (2007). Development Implication of Nigeria's Economic Crisis' J. Dev. Persp. 2(1): 34-59.

Dwivedi OP (1967). Bureaucratic Corruption in Developing Countries, Asian Review

Obadan M (2002). Corruption, Public Investment and Growth in Nigeria Some Stylist Facts NESG Economic Indicators 2 (2)

Kolade, C. C. (1999). Panel Report on Corruption in Nigeria. Africa Confidential, 4th August, 2000.

Ogboru, I. (2009). Reflections on External Debt, Corruption and Nigeria Economy. Jos University Press. 